\title{
CHARACTERISTICS OF THE ANTIVASOCONSTRICTOR EFFECT OF PINACIDIL ON ISOLATED
} RADIAL ARTERY

\author{
GOJKOVIĆ-BUKARICA LJILJANA*, STOJNIĆ NATAŠA*, PERIĆ M**, CVEJIĆ JELENA***,

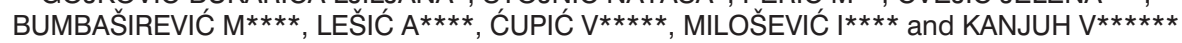 \\ *University of Belgrade, Faculty of Medicine, Serbia; \\ **Institute for Cardiovascular Diseases "Dedinje", Belgrade, Serbia; \\ ***Faculty of Medicine, Novi Sad, Serbia; \\ $\star * \star \star$ Institute of Orthopedics and Traumatology, Clinical Center of Serbia, Belgrade \\ $\star \star * \star \star \star$ University of Belgrade, Faculty of Veterinary Medicine, Serbia; \\ $\star \star \star \star * \star$ Serbian Academy of Sciences and Arts, Belgrade \\ (Received 25th October 2009)
}

Pinacidil, a prevously studied potassium channel opener (PCO), is a potent antihypertensive agent in animals and humans. Its mechanism of action is not completly defined. The aim of our study was to investigate the antivasoconstricting effect of pinacidil on the isolated $R A$ and to study whether this effect is endothelium-dependent. Contractions of isolated RA rings with intact endothelium were provoked by electrical field stimulation (EFS, $20 \mathrm{~Hz}$ ) or exogenously applied noradrenaline (NA, $10 \mu M)$. Pinacidil (10 nM-0.1 mM) produced a concentration-dependent inhibition of both EFS- and NA-evoked contractions $(p>0.05)$. NO synthesis inhibitor, L-NAME $(10 \mu M)$ and the guanylate cyclase inhibitor, methylene blue $(10 \mu M)$ did partly antagonize NA-evoked contractions and were without effect on EFSinduced contractions. Thus, the antivasoconstrictor effect of pinacidil on RA is partly endothelium-dependent and probably mediated via cGMP-dependent NO-pathway.

Key words: electrical field stimulation, pinacidil, radial artery

\section{INTRODUCTION}

Pinacidil, a prevously studied potassium channel opener (PCO), is a potent antihypertensive agent in animals and humans. PCOs are a class of drugs that has the ability to open $\mathrm{K}^{+}$channels and to produce hyperpolarization and relaxation of vascular smooth muscle cells. Recently they have been used in hyperpolarizing cardioplegia which has a protective role on endothelial function in coronary microcirculation (Yang and He, 2005). Mechanism of action of pinacidil isn't fully determined and involves opening of various types of $\mathrm{K}^{+}$channels (Bychkov et al., 1997). However, pinacidil has some additional $\mathrm{K}^{+}$-channelindependent mechanism(s), most probably stimulation of the forward mode of $\mathrm{Na}^{+}-\mathrm{Ca}^{2+}$ exchanger (Stojnic et al., 2007; Tsang et al., 2003). 
Some studies have shown that pinacidil produces endothelium-dependent vasodilatation, since removal of endothelium reduced in vivo the maximal relaxation of dog coronary arteries by $75 \%$ (Ghaleh et al., 1995). Deka et al. (1998) have shown that treatment of endothelium-intact rings of goat coronary artery with the NO synthesis inhibitor L-NAME or the guanylate cyclase inhibitor, methylene blue resulted in a marked inhibition in the relaxant responses to pinacidil. There are also studies, performed on animals, which supports opinions that pinacidilinduced vascular relaxation is a direct effect mediated by a novel, still unknown mechanisms (Quast, 1993).

The effect of pinacidil on neurogenic contractions of radial artery (RA) hasn't been studied yet. Since neurogenic contractions can contribute to the development of vascular spasm, the current study was performed in order to investigate the mechanism of the antivasoconstrictor effect of pinacidil on neurogenic contractions of RA and to study whether this effect is endotheliumdependent.

\section{MATERIALS AND METHODS}

Remaining segments of left RA $(n=67)$ were taken from male patients during bypass operation. Only arteries without macroscopic evidence of atherosclerosis were used. Research has been carried out in accordance to the Declaration of Helsinki (2000) of the World Medical Association. The vessel segments were taken within 10 min after clamping blood flow, placed in cold $\left(4^{\circ} \mathrm{C}\right)$ Krebs-Ringer-bicarbonate solution (mmol/L: $\mathrm{NaCl} 120, \mathrm{KCl} 5, \mathrm{CaCl}_{2} 2.5, \mathrm{MgSO}_{4}$ 1.2, $\mathrm{NaHCO}_{3} 25, \mathrm{KH}_{2} \mathrm{PO}_{4}$ 1.2, glukose 11, $\mathrm{Na}_{2}$ EDTA 0.032) and taken to the lab immediately.

\section{Artery segment preparations}

The artery segments were dissected from connective tissue and cut into 3 $\mathrm{mm}$ rings. From each patient were obtained 2 - 3 rings. When necessary, the endothelium was removed mechanically by rubbing it with a steel wire. Vessels' rings were mounted on two stainless steel wires in a $10 \mathrm{~mL}$ organ bath with KrebsRinger-bicarbonate solution $\left(37^{\circ} \mathrm{C}, \mathrm{pH} 7.4\right)$ aerated with $95 \% \mathrm{O}_{2}$ and $5 \% \mathrm{CO}_{2}$. One of the wire hooks was connected to the transducer (F30; Hugo Sachs, Freiburg, Germany), amplifier (301; Hugo Sachs, Freiburg, Germany) and recording system (R60; Rikadenki, Tokyo, Japan) that recorded changes in isometric tension. The other wire hook was attached to the displacement unit allowing fine adjustments of passive tension.

The preparations were equilibrated for $60 \mathrm{~min}$ and washed every $15 \mathrm{~min}$ with fresh buffer during this period. All vessels were then gradually passively stretched to an optimal resting tension, determined in a way previously described by our group (Stojnic et al., 2007).

Experimental procedure

After $15 \mathrm{~min}$ of equilibration, the presence of functional endothelium was assessed. Rings were precontracted with phenylephrine $(10 \mu \mathrm{M})$ and 
Acta Veterinaria (Beograd), Vol. 60, No. 2-3, 145-154, 2010.

Gojković-Bukarica Ljiljana et al.: Characteristics of

the antivasoconstrictor effect of pinacidil on isolated radial artery

acetylcholine $(20 \mu \mathrm{M})$ was added to the organ bath. If the maximal relaxant effect was more than $80 \%$ of the initial contraction, we considered functional endothelium to be present.

\section{Contractions of the RA evoked by EFS:}

Intramural nerves were stimulated using two platinum wire electrodes. The repetitive transmural EFS was carried out at $20 \mathrm{~Hz}$ with square wave pulses of 0.3ms duration and supramaximal voltage. Trains of pulses of 3-s duration were delivered from a Grass S44 electronic stimulator at 2 min intervals $(12,13)$.

The preparations were allowed to stabilize for at least $30 \mathrm{~min}$ until twitch responses became consistent, before addition of drugs. The concentrationresponse curve was constructed by addition of pinacidil directly to the bathing solution in a cumulative way, taking the amplitude of response measured immediately before the addition of a drug as a control (100\%). Higher concentrations of pinacidil were added only when the previous concentration has produced an equilibrium response.

In separate experiments, after twitch responses became consistent, the enzyme inhibitor (L-NAME, methylene blue- MB) was added into the bathing solution at least 20 min before exposure to pinacidil. Addition of these drugs did not modify the basal contractions of RA $(n=5)$ evoked by EFS. The amplitude of the response measured immediately before addition of pinacidil was taken as the control (100\%).

In order to confirm that EFS-induced contractions are mediated by neurotransmitter release from the sympathetic nerves, tetrodotoxin (1 $\mu \mathrm{M})$ or phentolamine $(1 \mu \mathrm{M})$ was added into the bathing solution, 20 min before applying EFS.

Contraction of the RA evoked by exogenous NA:

In a separate series of experiments, preparations not subjected to EFS were challenged repeatedly, for 2 min at 45-min intervals, with NA (10 $\mu \mathrm{M})$ to produce contractions similar in shape (maximal amplitude and slope) to those evoked by EFS. After achieving the maximal amplitude of the phasic contraction induced by exogenous NA, the arterial preparation was washed to prevent the development of sustained (tonic) contractions. Pinacidil was added into the medium for $10 \mathrm{~min}$, and the preparation was rechallenged to NA. The control exposure to NA was taken as $100 \%$ response. The antivasoconstrictor effect of pinacidil was then investigated in the presence of the enzyme inhibitor (L-NAME, MB). These drugs alone did not modify the basal contractions of RA $(n=4)$ evoked by exogenous NA.

Data and statistical analysis

The results are expressed as mean \pm standard error of mean (S.E.M.); $n$ refers to the number of trials. The least squares method was used for calculating linear regression. The concentration of pinacidil producing $50 \%$ of the maximum response $\left(E_{50}\right)$ was determined graphically for each curve by linear interpolation. The $\mathrm{EC}_{50}$ values are presented as $\mathrm{pEC}_{50}\left(-\log \mathrm{EC}_{50}\right)$. The statistical 
difference between means was determined by one-way ANOVA and Student's $t$ test, a value of $p<0.05$ was considered statistically significant.

\section{Drugs}

The following drugs were used: (R)-(-)-phenylephrine hydrochloride, Lnoradrenaline (NA), tetrodotoxin, phentolamine, pinacidil, N-nitro-L-argininemethyl ester hydrochloride (L-NAME) and methylene blue (MB) (Sigma-Aldrich Inc., St. Louis, MO, USA). Pinacidil was dissolved in $0.01 \mathrm{~N} \mathrm{HCl}$ and all other drugs were dissolved in distilled water. Previous experiments have shown that the solvents used had no effect on preparations at the concentrations applied. All drugs were added directly to the bath in a volume of $100 \mu \mathrm{M}$ and the concentrations given are the calculated final concentrations in the bath solution.

\section{RESULTS}

Effects of tetrodotoxin and $\alpha$-adrenoceptor blockade on EFS induced contractions

Tetrodotoxin $(1 \mu \mathrm{M})$ completely abolished the EFS evoked contractions of $R A(n=4)$. Phentolamine $(1 \mu M)$ reduced the EFS evoked contractions of RA $(92 \pm$ $2 \%, n=4)$. Data are not shown.

\section{Effects of pinacidil on EFS-evoked contractions and exogenous NA-induced} contractions of $R A$

Original recording of the inhibitory effect of pinacidil on EFS- and NAevoked contractions of RA with endothelium is shown in Figure $1 A$ and $1 B$, respectively. Comparative analysis has shown that in RA with endothelium there
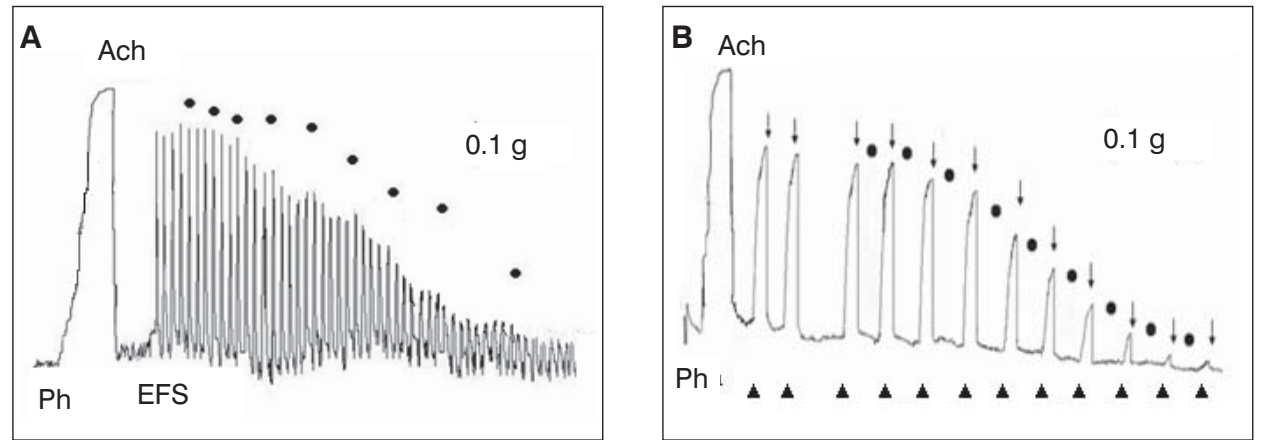

Figure 1 Representative experiments showing antivasoconstrictor effect of pinacidil in the human radial artery. To asses the endothelial integrity of the preparation acetylcholine (Ach) was used. Relaxation of phenylephrine (Ph) precontracted arteries greater than $80 \%$ was considered to indicate a state of endothelial preservation. Contractions of RA were evoked by electrical field stimulation (EFS, $20 \mathrm{~Hz}-\mathrm{A}$ ) or exogenously applied noradrenaline (NA, $10 \mu \mathrm{M}$, black triangle - B). After 3-min period NA-evoked contraction was ceased by wash-out (arrow). Cumulative concentrations of pinacidil (black circle) were added to the organ-bath 
was no difference $(p>0.05)$ in $E_{50}$ values and maximal response to pinacidil $\left(E_{\max }\right)$ in the inhibition of neurogenic and NA-evoked contractions (Fig. 2). Pinacidil (10 nM- $100 \mathrm{mM}$ ) produced a concentration-dependent inhibition of both EFS-induced contractions $\left(\mathrm{EC}_{50}=1.52 \pm 0.10 \mu \mathrm{M}, \mathrm{E}_{\max }=94 \pm 4 \%, \mathrm{n}=12\right)$ and contractions evoked by exogenous $\mathrm{NA}\left(\mathrm{EC}_{50}=1.16 \pm 0.10 \mu \mathrm{M}, \mathrm{E}_{\max }=96 \pm 3 \%\right.$, $n=7$ ) of the RA.

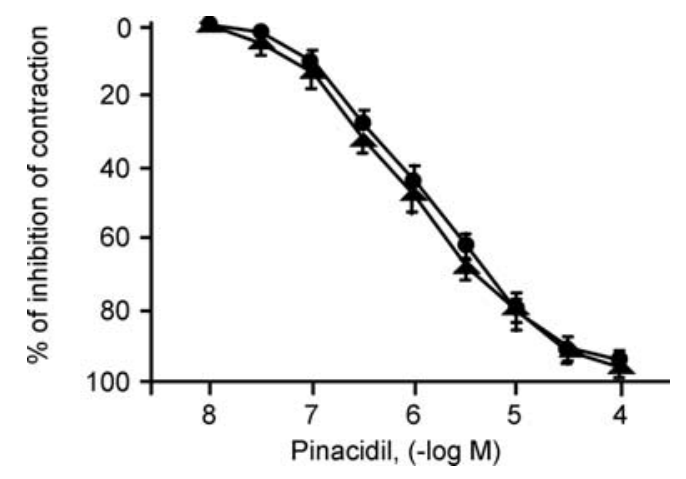

Figure 2. Concentration-dependent curve of antivasoconstrictor effect of pinacidil in the human radial artery. Contractions of radial artery with endothelium were evoked by electrical field stimulation (circles) or noradrenaline (triangles). The effects are expressed as \% of inhibition of control contraction. Each point represents mean \pm S.E.M. $(n=16) .{ }^{*} p<0.05$

Effects of L-NAME and methylene blue on pinacidil-induced inhibition of neurogenic contractions and contractions evoked by exogenously applied NA on the RA

L-NAME (10-100 $\mu \mathrm{M})$ did not antagonize the inhibitory action of pinacidil on neurogenic contractions elicited by EFS $\left(\mathrm{EC}_{50}=1.12 \pm 0.09 \mu \mathrm{M}\right.$ for control, $\mathrm{n}=5$; $0.76 \pm 0.12 \mu \mathrm{M})$ in the presence of $10 \mu \mathrm{M}$ L-NAME $(\mathrm{n}=5 ; 1.18 \pm 0.09 \mu \mathrm{M})$, in the presence of $100 \mu \mathrm{M}$ L-NAME $(n=5 ; p>0.05)$ (data not shown). However, L-NAME $(10 \mu \mathrm{M})$ partially antagonizes the inhibitory action of pinacidil $(10 \mu \mathrm{M})$ on contractions evoked by exogenously applied NA in RA with endothelium (\% of control contraction: $22 \pm 3 \%$ in the absence vs. $41 \pm 3 \%$ in the presence of $L$ NAME, $\mathrm{p}<0.05, \mathrm{n}=5$ ) (Fig $3 \mathrm{~A}$ and Table 1).

MB $(10-30 \mu \mathrm{M})$ was also without effect on pinacidil-induced inhibition of neurogenic contractions of $\mathrm{RA}$ with endothelium $\left(\mathrm{EC}_{50}=1.08 \pm 0.12 \mu \mathrm{M}, \mathrm{n}=5\right.$ vs. $0.96 \pm 0.10 \mu \mathrm{M}, \mathrm{n}=5$, in the presence of $10 \mu \mathrm{M} \mathrm{MB}$ and $0.80 \pm 0.12 \mu \mathrm{M}, \mathrm{n}=5$, in the presence of $30 \mu \mathrm{M} M B, p>0.05$, all) (data not shown). Similarly to previous results, $\mathrm{MB}(10 \mu \mathrm{M})$ did partially antagonize the inhibitory action of pinacidil $(10 \mu \mathrm{M})$ on NA-evoked contractions of RA with endothelium (\% of control 
contraction: $23 \pm 3 \%$ in the absence vs. $56 \pm 2 \%$ in the presence of $M B, p<0.05$, $\mathrm{n}=5$ ) (Fig 3B and Table 1).
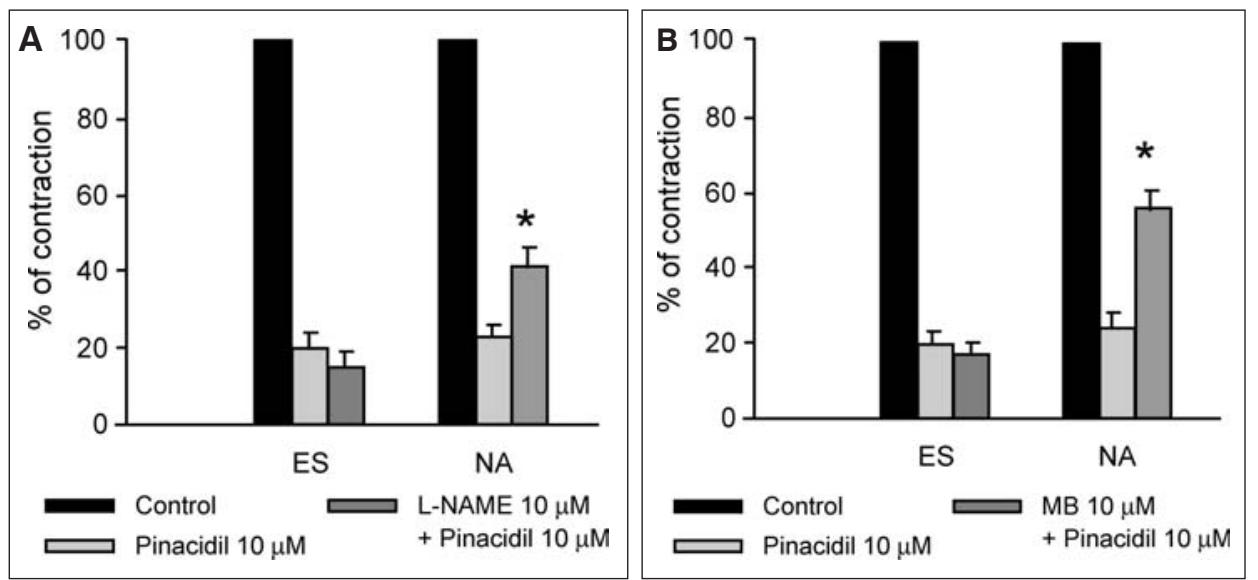

Figure 3. Effects of enzyme inhibitors: L-NAME $(10 \mu \mathrm{M})(\mathrm{A})$ and $\mathrm{MB}(10 \mu \mathrm{M})(\mathrm{B})$ on the antivasoconstrictor action of pinacidil in the RA with endothelium. The contractions were evoked by electical field stimulation (ES, $20 \mathrm{~Hz}$; left bars) or by exogenous noradrenaline (NA, $10 \mu \mathrm{M}$; right bars). The amplitude of contraction measured just before addition of drugs was taken as the control contraction (100\%). Effects are expressed as a percentage of the control contraction. Each bar represents the mean \pm S.E.M. $(n=5){ }^{*} p<0.05$

Table 1. Effect of enzyme inhibitors on the pinacidil-induced inhibition of contractions of the human radial artery. Contractions were evoked by electrical filed stimulation (EFS, $20 \mathrm{~Hz}$ ) or exogenous noradrenaline (NA, $10 \mu \mathrm{M}$ )

\begin{tabular}{|l|c|c|}
\hline \multirow{2}{*}{ Contraction condition } & EFS-evoked contraction & NA-evoked contraction \\
\cline { 2 - 3 } & $\begin{array}{c}\text { \% of control contraction } \\
\text { (mean } \pm \text { S.E.M., } \mathrm{n}=5)\end{array}$ & $\begin{array}{c}\text { \% of control contraction } \\
\text { (mean } \pm \text { S.E.M., } \mathrm{n}=5 \text { ) }\end{array}$ \\
\hline \hline Control (with endothelium) & $100 \%$ & $100 \%$ \\
\hline Pinacidil $10 \mu \mathrm{M}$ & $19 \pm 3 \%$ & $22 \pm 3 \% *$ \\
\hline L-NAME $10 \mu \mathrm{M}+$ Pinacidil $10 \mu \mathrm{M}$ & $17 \pm 2 \%$ & $41 \pm 3 \% *$ \\
\hline \hline Pinacidil $10 \mu \mathrm{M}$ & $21 \pm 2 \%$ & $23 \pm 3 \% *$ \\
\hline MB $10 \mu \mathrm{M}+$ Pinacidil $10 \mu \mathrm{M}$ & $18 \pm 3 \%$ & $56 \pm 2 \% *$ \\
\hline
\end{tabular}

${ }^{*} \mathrm{p}<0.05 ; \mathrm{L}-\mathrm{NAME}=\mathrm{N}$-nitro-L-arginine-methyl ester hydrochloride; $\mathrm{MB}=$ methylene blue 
Acta Veterinaria (Beograd), Vol. 60, No. 2-3, 145-154, 2010.

\section{DISCUSSION}

It is well established that EFS of perivascular nerve terminals on isolated blood vessels releases various neurotransmitters and co-transmitters (noradrenaline, ATP, neuropeptide $Y$ ) which contribute to the development of contractions (Smyth et al., 2000). To validate the effect of transmural EFS on the isolated blood vessels, we applied tetrodotoxin $(1 \mu \mathrm{M})$ in a concentration that selectively paralyzes nerve endings. The confirmation of the neurogenic nature of the contraction induced by EFS in our experiments was obtained by $100 \%$ inhibition of EFS-induced contractions of the RA by tetrodotoxin. In order to further define the site of action/mechanisms of EFS-induced contractions of the RA we used phentolamine. A significant reduction of EFS-induced contraction by phentolamine (>80\%) indicates that NA released from perivascular sympathetic nerve endings acts on vascular, postjunctional $\alpha$-adrenoceptors. He and Yang (1998) have shown that predominant adrenoreceptors in human RA are $\alpha_{1}$ and to a lesser extent $\alpha_{2}$.

Histological studies have identified nerve fibres in the tunica adventitia of human RA (Barry et al., 2003). Recently, it has been shown by our group of authors (Stojnic et al., 2006; Pagan et al., 2009) that electrical filed stimulation (EFS) of the human and porcine RA is mainly mediated by NA release from perivascular nerves. Morfological studies revealed the presence of noradrenergic nerve fibres in the tunica adventitia and in the adventitia-media boundary of the porcine RA wall. The neurogenic contraction of this artery is modulated by $\mathrm{Ca}^{2+}$ activated $\left(\mathrm{K}_{\mathrm{Ca}}\right)$ and voltage-dependent $\mathrm{K}^{+}\left(\mathrm{K}_{\mathrm{V}}\right)$ channels (Pagan et al., 2009). EFS produces depolarization of nerve endings, leading to activation of voltagesensitive $\mathrm{Ca}^{2+}$ channels, influx of extracellular $\mathrm{Ca}^{2+}$ and release of neurotransmitters. Depolarization also produces activation of $\mathrm{K}_{\mathrm{v}}$ channels, while an increase in intracellular $\mathrm{Ca}^{2+}$ is followed by opening of $\mathrm{K}_{\mathrm{Ca}}$ channels, efflux of $\mathrm{K}^{+}$and hyperpolarization of the cell. These subsequent events may act as a negative feedback mechanism in neurotransmitter release (Teramoto, 2006, Pagan et al., 2009).

PCOs are a class of drugs that has the ability to open $\mathrm{K}_{\text {ATP }}$ channels to produce hyperpolarization and relaxation of vascular smooth muscle cells. Recently, they have been used in hyperpolarizing cardioplegia which has a protective role on endothelial function in coronary microcirculation (Yang and $\mathrm{He}$, 2005). Pinacidil is a previously studied PCO whose mechanism of action is very well established and for this reason it is a useful pharmacological tool for the study of $\mathrm{K}^{+}$channels (Quast, 1993; Bychkov et al., 1997). We have shown previously that pinacidil is a potent vasodilator of human RA precontracted with phenylephrine, and it seems that the mechanism of action of pinacidil on the RA involves activation of smooth muscle glibenclamide- and TEA-sensitive $\mathrm{K}^{+}$ channels, but not 4-aminopyridine (4-AP) sensitive channels (Stojnic et al., 2007). It was previously shown in different animal models that pinacidil has inhibitory effects on both EFS- and NA-evoked contractions (Cai et al., 1994). This is the first study of the inhibitory effects of pinacidil on electrically-evoked contractions of RA. The pinacidil-induced endothelium-independent inhibition of neurogenic 
contractions of RA are of a potency comparable to those of the rat ileum (Davies et al., 1996) and rabbit portal vein (Gojkovic-Bukarica and Kazic, 1999). When contractions were evoked by exogenously applied NA sensitivity of RA to the inhibitory action of pinacidil was significantly greater than those of the rabbit portal vein, thus suggesting that it could have a therapeutic potential in the prevention of spasm. Our finding that the effect of pinacidil is partly endothelium-dependent is comparable to results of Ghaleh et al. (1995). However, our group has previously shown that the vasodilatatory effect of pinacidil on RA is not endotheliumdependent, but in that study a different experimental protocol was used.

L-NAME is a non-selective inhibitor of NO-syntase, which inhibits all three isoforms of this enzyme responsible for production of NO (Handy and Moore, 1998). MB is a well established inhibitor of guanilate-cyclase, which produces cGMP. Neither of these enzyme inhibitors did affect the inhibitory effect of pinacidil on EFS-evoked contractions of RA. However, when contractions of RA were evoked by exogenously applied NA acting postsynaptically, these two enzyme inhibitors applied in a low concentration $(10 \mu \mathrm{M})$ did partly antagonize the inhibitory effect of pinacidil suggesting NO involvement. Deka et al. (1998) have also shown that vasodilation produced by pinacidil in the goat coronary artery could partly be inhibited by application of L-NAME and MB. This result supports our observation that cGMP-dependent NO-pathway plays a role in the inhibition of NA-evoked contractions of RA.

Our results show that pinacidil is a potent antivasoconstrictor agent on RA and that it can be considered as a potential drug in the prevention of RA spasm. Its mechanism of antivasoconstrictor action involves an endothelium-dependent component with increased release of NO and cGMP as the second messenger.

\section{ACKNOWLEDGEMENTS:}

We thank Mrs. Milena Zabunovic for technical support during this study. The studies in our laboratory are supported by a Scientific Research Grant from the Ministry of Science and Technology Serbia (TP 20027) .

Address for correspondence:

Ljiljana Gojković-Bukarica, PhD, M.D.

Department of Clinical Pharmacology, Pharmacology and Toxicology,

Faculty of Medicine, University of Belgrade

P.O. Box 38

Belgrade, Serbia

E-mail: I.g.bukarica@sezampro.rs

\section{REFERENCES}

1. Barry MM, Foulon P, Touati G, Ledoux B, Sevestre H, Carmi D et al., 2003, Comparative histological and biometric study of the coronary, radial and left internal thoracic arteries, Surg Radiol Ana, 225, 284-9.

2. Bychkov R, Gollasch M, Ried C, Luft FC, Haller H, 1997, Effects of pinacidil on K+ channels in human coronary artery vascular smooth muscle cells. Am J Physiol, 273: C161-71.

3. Cai B, Hao Q, Greenberg SS, deBoisblanc B, Gillott D, Goharderakhshan R et al., 1994, Differential effects of pinacidil and cromakalim on vascular relaxation and sympathetic neurotransmission, Can J Physiol Pharmacol, 72, 801-10. 
4. Davies MP, McCurrie JR, Wood D, 1996, Comparative effects of $\mathrm{K}+$ channel modulating agents on contractions of rat intestinal smooth muscle, Eur J Pharmacol, 297, 249-56.

5. Deka DK, Raviprakash V, Mishra SK, 1998, Basal nitric oxide release differentially modulates vasodilations by pinacidil and levcromakalim in goat coronary artery, Eur J Pharmacol, 348, 1123.

6. Ghaleh B, Dubois-Randé JL, Hittinger L, Giudicelli JF, Berdeaux A, 1995, Comparisons of the effects of nicorandil, pinacidil, nicardipine and nitroglycerin on coronary vessels in the conscious dog: role of the endothelium, Br J Pharmacol, 114, 496-502.

7. Gojkovic-Bukarica Lj, Kazic T, 1999, Differential effects of pinacidil and levcromakalim on the contractions elicited electrically or by noradrenaline in the portal vein of the rabbit, Fundam Clin Pharmacol, 13, 527-34

8. Handy RL, Moore PK, 1998, A comparison of the effects of L-NAME, 7-NI and L-NIL on carrageenaninduced hindpaw oedema and NOS activity, Br J Pharmacol, 123, 1119-26.

9. He GW, Yang CQ, 1998, Characteristics of adrenoreceptors in the human radial artery: clinical implications, J Thorac Cardiovasc Surg, 115, 1136-41.

10. Pagán RM, Martínez AC, Martínez MP, Hernández M, García-Sacristán A, Correa C et al., 2009, Endothelial and potassium channel dependent modulation of noradrenergic vasoconstriction in the pig radial artery, Eur $J$ Pharmacol (in press).

11. Quast U, 1993, Do the K+ channel openers relax smooth muscle by opening K+ channels? Trends Pharmacol Sci, 14, 332-7.

12. Smyth L, Bobalova J, Ward SM, Keef KD, Mutafova-Yambolieva VN, 2000, Cotransmission from sympathetic vasoconstrictor neurons: differences in guinea-pig mesenteric artery and vein, Auton Neurosci, 86, 18-29.

13. Stojnic N, Bukarica LG, Peric M, Bumbasirevic M, Lesic A, Lipkovski JM et al., 2006, Analysis of vasoreactivity of isolated human radial artery, $J$ Pharmacol Sci, 100, 34-40.

14. Stojnic N, Gojkovic-Bukarica L, Peric M, Grbovic L, Lesic A, Bumbasirevic M et al., 2007, Potassium channel opener pinacidil induces relaxation of the isolated human radial artery, $J$ Pharmacol Sci, 104, 122-9.

15. Teramoto N, 2006, Physiological roles of ATP-sensitive $\mathrm{K}^{+}$channels in smooth muscle, J Physiol, 572, 617-24.

16. Tsang SY, Yao X, Wong CM, Au CL, Chen ZY, Huang Y, 2003, Contribution of Na+ -Ca2+ exchanger to pinacidil-induced relaxation in the rat mesenteric artery, $\mathrm{Br} J$ Pharmacol, 138, 453-60.

17. Yang Q, He GW, 2005, Effect of cardioplegic and organ preservation solutions and their components on coronary endothelium-derived relaxing factors, Ann Thorac Surg, 80, 757-67.

\title{
ANTIVAZOKONSTRIKTORNI EFEKT PINACIDILA NA IZOLOVANOJ RADIJALNOJ ARTERIJI
}

\author{
GOJKOVIĆ-BUKARICA LJILJANA, STOJNIĆ NATAŠA, PERIĆ M, CVEJIĆ JELENA \\ BUMBAŠIREVIĆ M, LEŠIĆ A, ĆUPIĆ V, MILOŠEVIĆ I i KANJUH V
}

\section{SADRŽAJ}

Pinacidil je "otvarač" kalijumovih kanala (OKK) koji ima snažno antihipertenzivno dejstvo na životinjama i ljudima. Mehanizam dejstva pinacidila još uvek nije u potpunosti definisan. Zato je cilj naše studije bio da ispitamo da li je antivazokonstriktorno dejstvo pinacidila na izolovanoj radijalnoj arteriji (RA) čoveka en- 
dotel zavisno. Kontrakcije prstenova RA sa očuvanim endotelom su prouzrokovane električnom stimulacijom (EFS, $20 \mathrm{~Hz}$ ) ili spolja dodatim noradrenalinom (NA, $10 \mu \mathrm{M})$. Pinacidil ( $10 \mathrm{nM}-0.1 \mathrm{mM}$ ) je prouzrokovao koncentracijski-zavisnu inhibiciju EFS- i NA-kontrakcija bez značajne razlike u senzitivnosti $(p>0.05)$. Inhibitor sinteze NO-a, L-NAME $(10 \mu \mathrm{M})$ i inhibitor gvanilat ciklaze, metilensko plavo $(10 \mu \mathrm{M})$ su delimično antagonizovali inhibitorni efekt pinacidila na NA-kontrakcije. Nasuprot ovome, oni nisu uticali na efekt pinacidila na EFS-kontrakcije. Možemo da zaključimo da pinacidil ima antivazokonstriktorni efekt na RA kada su kontrakcije izazvane električnom strujom ili noradrenalinom. Ovaj efekt pinacidila je delom endotel zavisan, ali samo kada su kontrakcije izazvane spolja dodatim noradrenalinom. 